\title{
Agen Cerdas Untuk Perilaku Reward Appreciative Learning Dalam Game Pendidikan Kewirausahaan
}

Intelligent Agent for Appreciative Learning Reward Behaviour in Entrepreneurship Education Game

\author{
Hanny Haryanto ${ }^{1}$, Acun Kardianawati ${ }^{2}$, Umi Rosyidah ${ }^{3}$ \\ ${ }^{1,3}$ Program Studi Teknik Informatika, Fakultas Ilmu Komputer, Universitas Dian Nuswantoro \\ Semarang, Jalan Imam Bonjol No.207 Semarang \\ ${ }^{2}$ Program Studi Sistem Informasi, Fakultas Ilmu Komputer, Universitas Dian Nuswantoro \\ Semarang, Jalan Imam Bonjol No.207 Semarang \\ E-mail: 'hanny.haryanto@dsn.dinus.ac.id, ${ }^{2}$ acunkardiana@gmail.com, \\ ${ }^{3}$ umi.rosyidah@dsn.dinus.ac.id
}

\begin{abstract}
Abstrak
Dalam game pendidikan kewirausahaan yang berfokus pada pemberian pengalaman praktis dan kognitif, personalisasi reward untuk aktivitas dalam game adalah salah satu elemen penting untuk memperkuat penyampaian materi pembelajaran. Namun, perancangan reward yang ada dalam game pendidikan seringkali tidak memiliki konsep yang baik sehingga menghasilkan suatu sistem reward yang acak dan monoton. Penelitian ini menggunakan reward yang disusun dengan konsep Appreciative Learning, yang berfokus pada hal-hal positif seperti puncak pencapaian, peluang, eksplorasi potensi dan optimisme masa depan. Aktivitas reward dengan konsep tersebut terdiri dari empat tahap, yaitu Discovery, Dream, Design dan Destiny. Personalisasi reward dilakukan dengan pengaturan perilaku reward oleh agen cerdas yang berjalan dalam keempat tahap tersebut. Agen cerdas bekerja dalam lingkungan game yang diskrit, deterministik dan statis. Agen cerdas akan mempunyai pengetahuan mengenai model lingkungan dan kondisinya. Perilaku agen cerdas dimodelkan menggunakan Finite State Machine. Penelitian ini menghasilkan perilaku reward dinamis pada lingkungan game pendidikan kewirausahaan yang dirancang dengan konsep Appreciative Learning.
\end{abstract}

Kata kunci-reward, agen cerdas,game pendidikan, kewirausahaan, Appreciative Learning.

\begin{abstract}
In entrepreneurship education games that focus on providing practical and cognitive experience, personalized rewards for in-game activities are an important element to strengthen the delivery of learning materials. However, the design of rewards that exist in educational games often do not have a good concept that impacted to a random and monotonous reward system. This study uses rewards compiled with the Appreciative Learning concept, which focuses on positive things such as peak achievement, opportunities, potential exploration and future optimism. The reward activity with the concept consists of four stages, namely Discovery, Dream, Design and Destiny. Personalized rewards are done using intelligent agent that setting up reward behavior which run in all four stages. Intelligent agent works in discrete, deterministic and static game environments. The intelligent agent will have knowledge of the environmental model and its condition. Intelligent agent behavior is modeled using Finite State Machine. This research resulted in a dynamic reward behavior in an entrepreneurship educational game environment designed with Appreciative Learning concepts.
\end{abstract}

Keyword - reward, intelligent agent, educational games, entrepreneurship, Appreciative Learning. 


\section{PENDAHULUAN}

Sebagai salah satu elemen penting dalam memajukan ekonomi di suatu negara, kewirausahaan menjadi materi yang masuk dalam kurikulum pengajaran di akademik. Kewirausahaan sendiri adalah proses usaha bisnis yang dimulai oleh seseorang atau kelompok orang dan umumnya disertai oleh inovasi untuk memperbesar usaha tersebut [1]. Orang yang menjalankan kewirausahaan umumnya disebut dengan pengusaha. Salah satu tujuan utama pembelajaran kewirausahaan adalah memotivasi dan membentuk jiwa kewirausahaan, namun masalah yang terjadi dalam pembelajaran kewirausahaan adalah materi yang didominasi oleh teori dan kognisi, sehingga tujuan utama pembelajaran tersebut belum dipenuhi dengan baik [2]. Karena kurangnya pengalaman praktis yang diberikan di akademik, motivasi dan konsep berwirausaha umumnya berasal dari lingkungan dan keluarga.

Penggunaan game pendidikan dipandang sebagai solusi yang efektif dalam memberikan pengalaman praktis pembelajaran, yang mempunyai kelebihan dalam menumbuhkan sikap positif dan kesenangan dalam mengikuti pembelajaran [3]. [4] menggunakan game untuk aktivitas pembelajaran pra sekolah dan merumuskan model pedagogiknya. Mereka mengungkapkan bahwa genre game tertentu, seperti Role Playing Game juga memiliki konten kognitif yang signifikan. Penelitian yang dilakukan oleh [5] menyimpulkan bahwa penggunaan game untuk pembelajaran dapat membentuk perilaku kerja sama, menciptakan motivasi belajar dan menyediakan pengalaman praktis kepada siswa. Dalam konteks pembelajaran kewirausahaan, [6] mengungkapkan kontribusi penggunaan game untuk mendukung pemahaman materi dalam pembelajaran kewirausahaan pada level pascasarjana. Model pembelajaran berbasis game untuk kewirausahaan juga dilakukan oleh [7] dan [8].

Dalam memperkuat pemahaman materi yang diberikan di dalam game pendidikan, elemen reward adalah salah satu bagian dalam game yang paling penting. Personalisasi reward dimaksudkan supaya pembelajar memiliki pengalaman yang berbeda dan unik sehingga menghasilkan memori yang mengesankan [9]. Reward umumnya memberikan umpan balik berupa evaluasi dan motivasi pada aksi yang dilakukan. Pada penelitian yang dilakukan oleh [10] menggunakan Finite State Machine untuk mengenali aksi dari pemain dan dilanjutkan oleh [11] yang merancang perilaku reward dinamis menggunakan model Finite State Machine. Namun, fokus dari penelitian tersebut hanya pada personalisasi reward dan tidak didasari konsep yang tepat sehingga reward yang dikembangkan tidak terkonsep dengan baik yang mengakibatkan sistem reward menjadi acak dan monoton.

Penelitian ini akan merancang agen cerdas untuk mengatur perilaku reward yang dibuat dengan konsep Appreciative Learning. Appreciative Learning yang merupakan konsep pembelajaran yang menekankan pada hal-hal positif, seperti pencapaian, peluang, potensi dan optimisme [12] akan digunakan untuk membentuk dan mengklasifikasikan perilaku reward, yang terbagi dalam empat tahap, yaitu Discovery, Dream, Design dan Destiny.

\section{METODE PENELITIAN}

\subsection{Tahapan Penelitian}

Tahapan pada penelitian ini terdiri dari tujuh langkah yang ditunjukkan pada Gambar 1 berikut. 


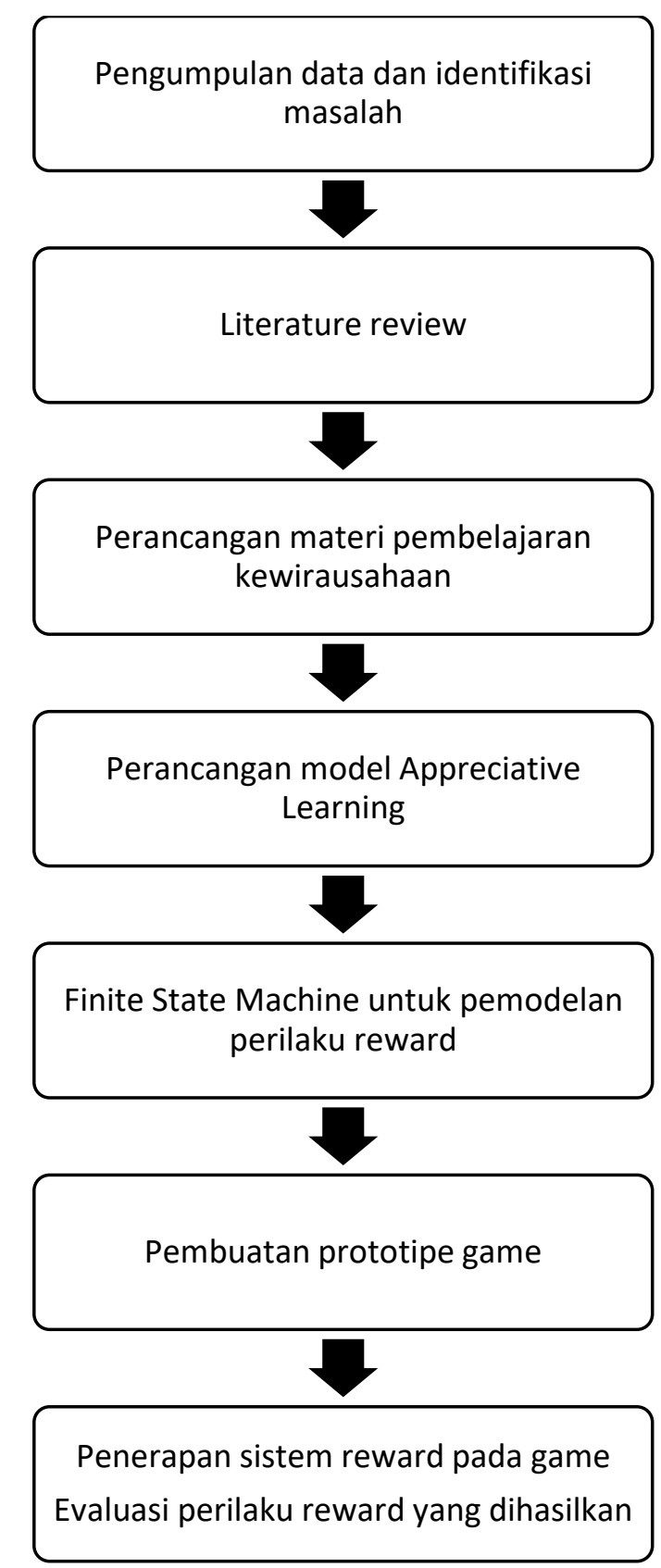

Gambar 1. Tahapan Penelitian 
2.2 Model Game

Gambaran umum dari rancangan game ditunjukkan pada Gambar 2 sebagai berikut.

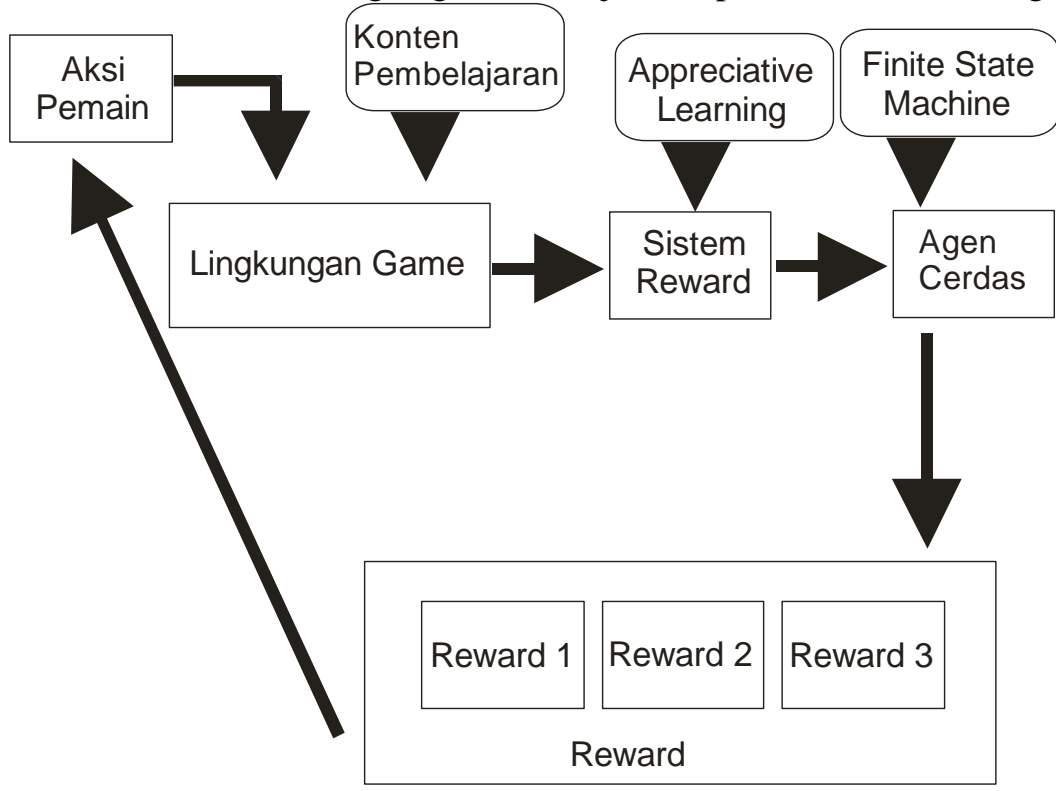

Gambar 2. Rancangan Game

Aksi user di lingkungan game pembelajaran akan ditangkap oleh sistem reward yang disusun menggunakan konsep Appreciative Learning. Kemudian agen cerdas berbasis Finite State Machine akan mengatur perilaku reward untuk memilih reward yang diberikan kepada pemain.

\subsection{Konsep Appreciative Learning}

Appreciative Learning adalah konsep yang diturunkan dari Appreciative Inquiry. Konsep ini berfokus pada hal-hal yang positif sebagai dasar dari pembelajaran [12]. Appreciative Learning terdiri dari empat tahapan aktivitas, seperti yang diperlihatkan pada Gambar 3 berikut.

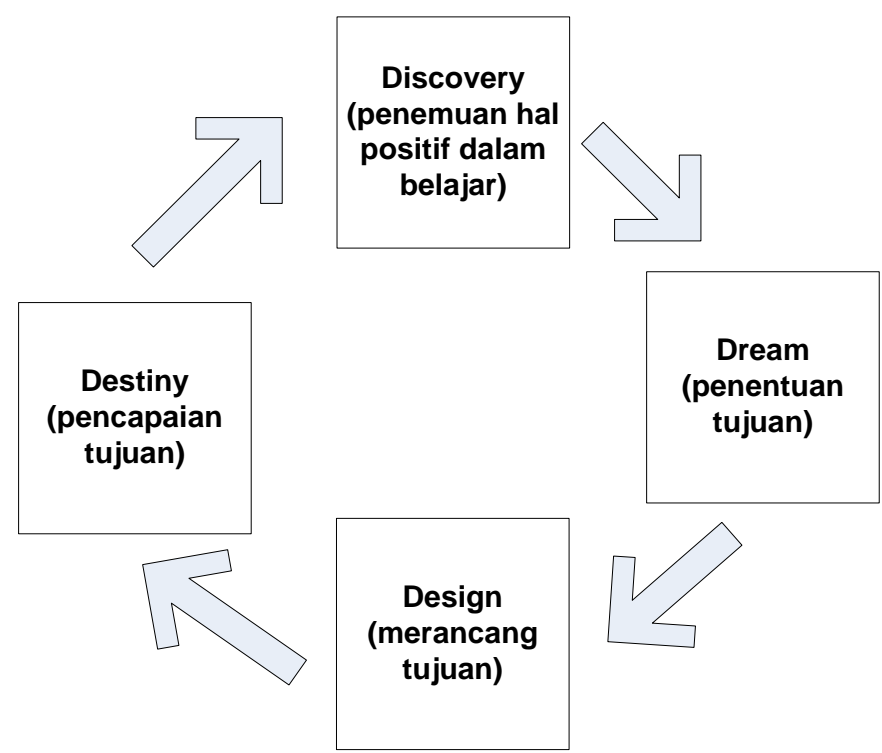

Gambar 3. Tahapan Appreciative Learning [12] 
Tahapan Discovery adalah penemuan hal-hal yang positif dalam materi pembelajaran. Kemudian setelah itu pada tahap Dream, dilanjutkan oleh penentuan tujuan yang berdasarkan hal-hal positif yang ditemukan. Tahap selanjutnya adalah Design, dimana pada tahap ini pembelajar mulai merancang hal yang menjadi tujuannya. Kemudian tahap terakhir adalah Destiny, dimana tahap ini pembelajar mewujudkan tujuannya. Aktivitas ini akan terus menerus berulang sebagai sebuah siklus.

\subsection{Rancangan Agen Cerdas}

Agen cerdas yang dibuat bekerja di lingkungan yang diskrit, deterministik dan statis [13]. Diskrit artinya jumlah aksi dan persepsi terbatas, deterministik memiliki arti bahwa satu aksi dapat diprediksi dari aksi sebelumnya, dan statis berarti lingkungan dalam game tidak berubah. Gambar 4 berikut menunjukkan rancangan dari agen cerdas.

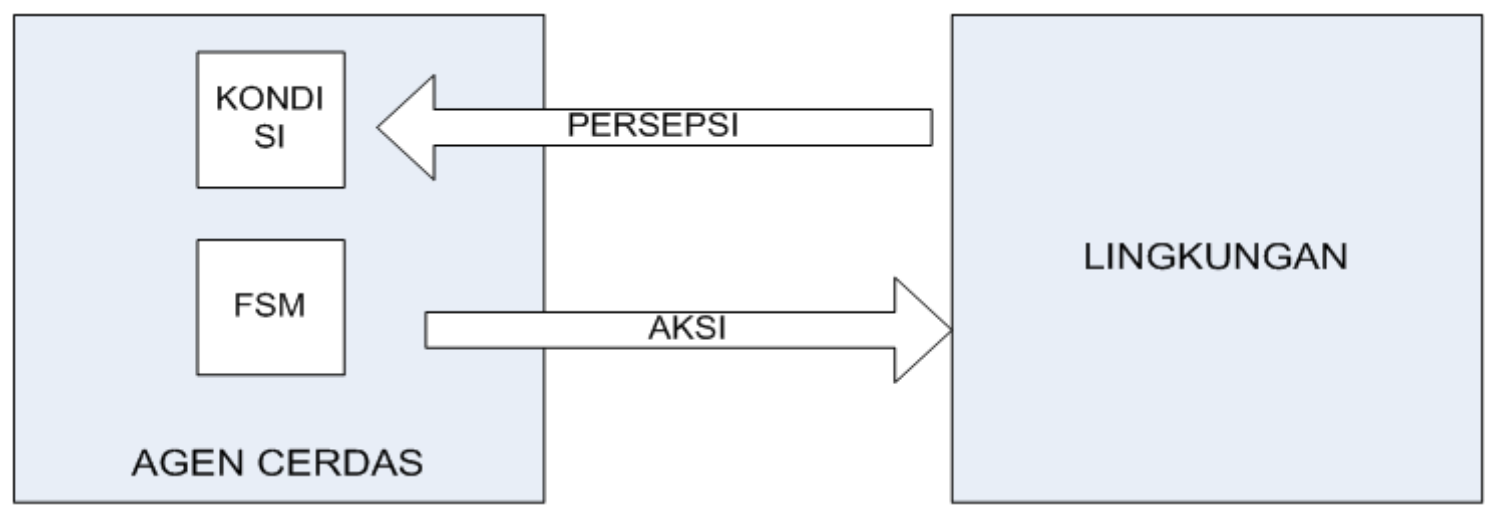

Gambar 4. Model Agen Cerdas

Agen cerdas dapat menerima kondisi dari lingkungannya kemudian melalui Finite State Machine dapat melakukan pemilihan terhadap aksi yang dilakukan.

\section{HASIL DAN PEMBAHASAN}

3.1 Pengelompokan konten pembelajaran pada Appreciative Learning

Seperti diperlihatkan pada Gambar 3, model Appreciative Learning memiliki empat tahapan yaitu Discovery, Dream, Design dan Destiny. Tabel 1 berikut memperlihatkan pengelompokan konten pembelajaran kewirausahaan pada tiap tahapan tersebut.

Tabel 1: Konten pembelajaran pada aktivitas Appreciative Learning

\begin{tabular}{|c|c|c|}
\hline No & Tahap & Konten Pembelajaran \\
\hline 1 & Discovery & $\begin{array}{l}\text { Pengenalan diri } \\
\text { Komunikasi } \\
\text { Jenis usaha }\end{array}$ \\
\hline 2 & Dream & $\begin{array}{l}\text { Investasi } \\
\text { Kerjasama } \\
\text { Jenis usaha }\end{array}$ \\
\hline 3 & Design & $\begin{array}{l}\text { Inovasi } \\
\text { Kreativitas } \\
\text { Kepemimpinan } \\
\text { Kerjasama } \\
\text { Investasi }\end{array}$ \\
\hline 4 & Destiny & Pemasaran \\
\hline
\end{tabular}




\begin{tabular}{|l|l|}
\hline & Komunikasi \\
& Kepemimpinan \\
& Kerjasama \\
\hline & Pengembangan usaha \\
& Tantangan usaha \\
\hline
\end{tabular}

\subsection{Finite State Machine untuk Perilaku Reward Adaptif}

Perilaku reward yang dihasilkan diatur oleh Finite State Machine. Perilaku reward dibagi untuk empat tahap, yaitu tahap Discovery, Dream, Design dan Destiny. Atribut-atribut yang digunakan sebagai kondisi untuk perubahan perilaku adalah komunikasi (CA), ketekunan (PA), kebijaksanaan (WA), kebermanfaatan (HA), kepercayaan (TA) dan reputasi. Agen cerdas mengatur perilaku reward sehingga pemain mendapatkan reward yang berbeda sesuai dengan apa yang dilakukan di dalam game. Reward utama adalah reward minimal yang harus didapatkan pemain untuk beralih ke tahap selanjutnya.

\subsubsection{Perilaku Reward pada tahap Discovery}

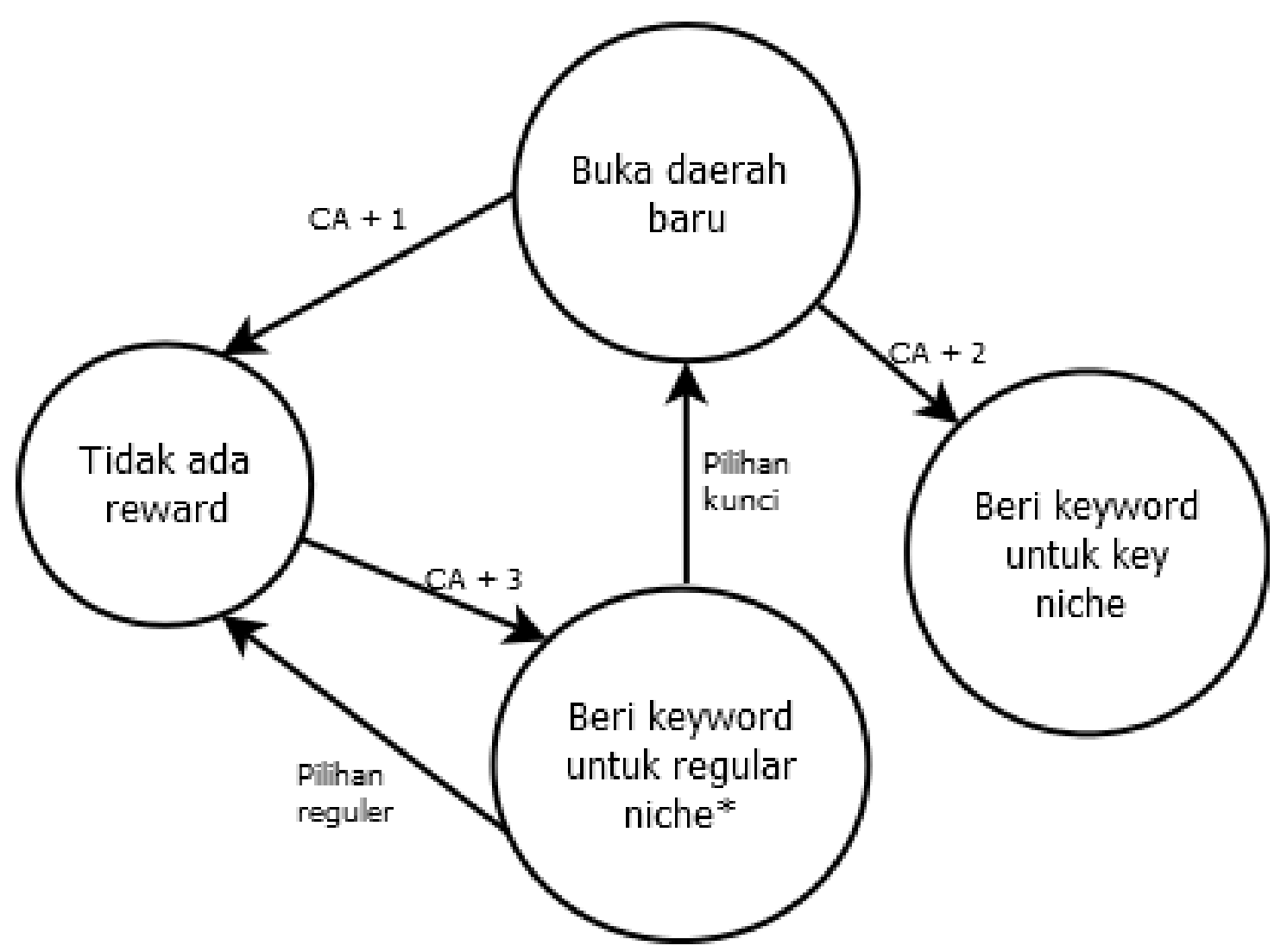

\section{$\mathrm{CA}=$ Communication Attribute}

*Reward utama

Gambar 5. Perilaku reward pada tahap Discovery

Pada tahap Discovery, atribut komunikasi memegang peranan utama. Disini agen cerdas akan membaca pilihan dari pemain yang akan menentukan penambahan nilai atribut komunikasi (CA). Agen cerdas akan memberi reward regular jika CA bertambah 3, dan jika bertambah 2 lagi maka agen cerdas akan memberi reward spesial. Pada tahap ini, pemain akan fokus menemukan kata kunci untuk produk yang akan dijual. 


\subsubsection{Perilaku Reward pada tahap Dream}

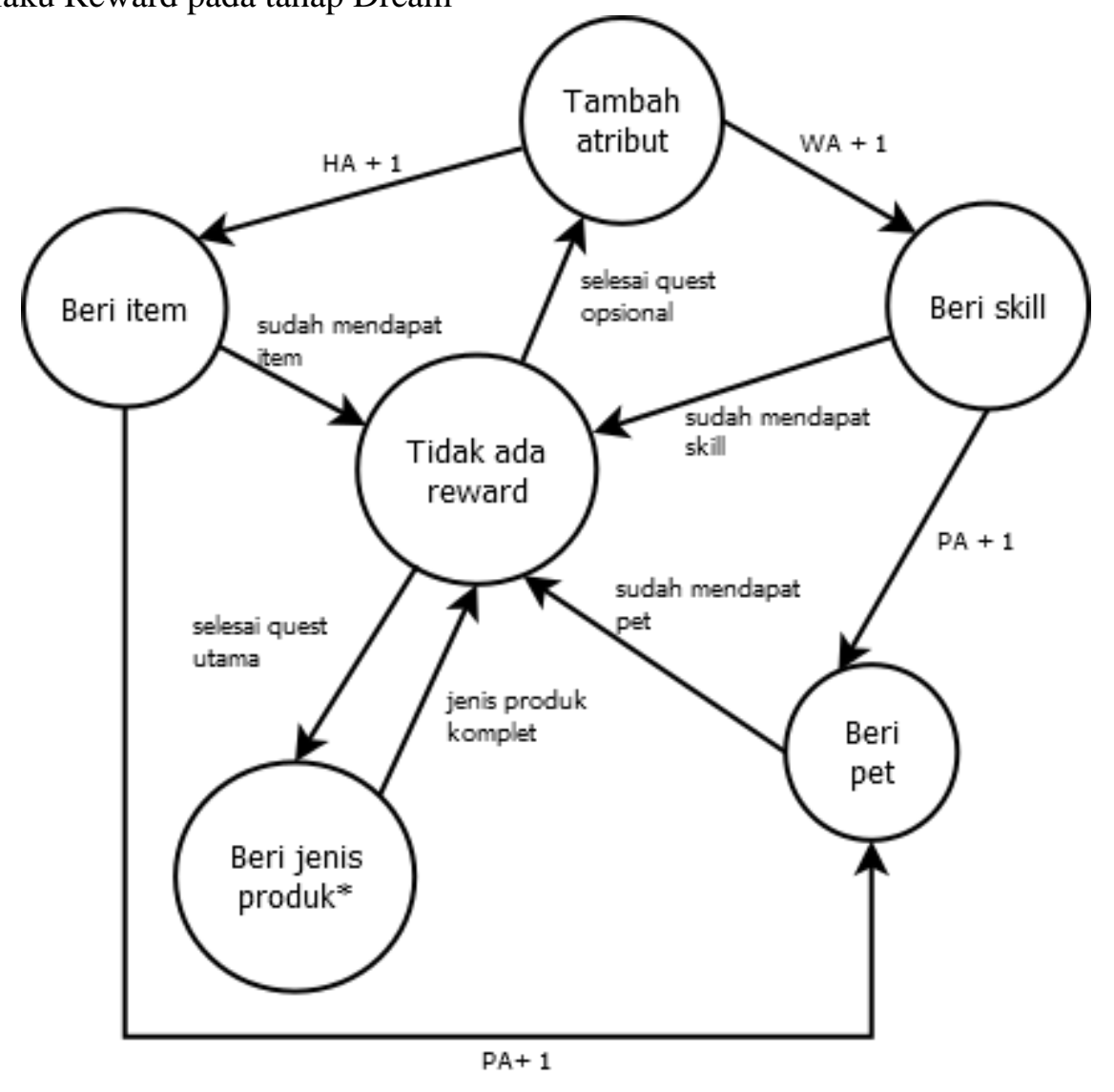

$$
\begin{aligned}
& \mathrm{PA}=\text { Perseverance Attribute } \\
& \text { WA = Wisdom Attribute } \\
& \mathrm{HA}=\text { Helpfulness Attribute } \\
& \text { * Reward utama }
\end{aligned}
$$

Gambar 6. Perilaku reward pada tahap Dream

Pada tahap Dream, jika pemain menyelesaikan misi selain misi utama maka akan mendapatkan reward berupa skill / item. Fokus utama dari tahap ini adalah mendapatkan jenis produk yang akan dijual. Pemain dapat menyelesaikan misi opsional untuk mendapatkan reward tambahan berupa skill / item / pet. Jenis reward tambahan yang didapat bergantung pada atribut kebermanfaatan (HA), kebijaksanaan (WA) dan ketekunan (PA). HA akan menghasilkan reward item, WA akan menghasilkan skill dan PA akan memberi pet kepada pemain. 
Techno.COM, Vol. 16, No. 3, Agustus 2017 : 325-336

\subsubsection{Perilaku Reward pada tahap Design}




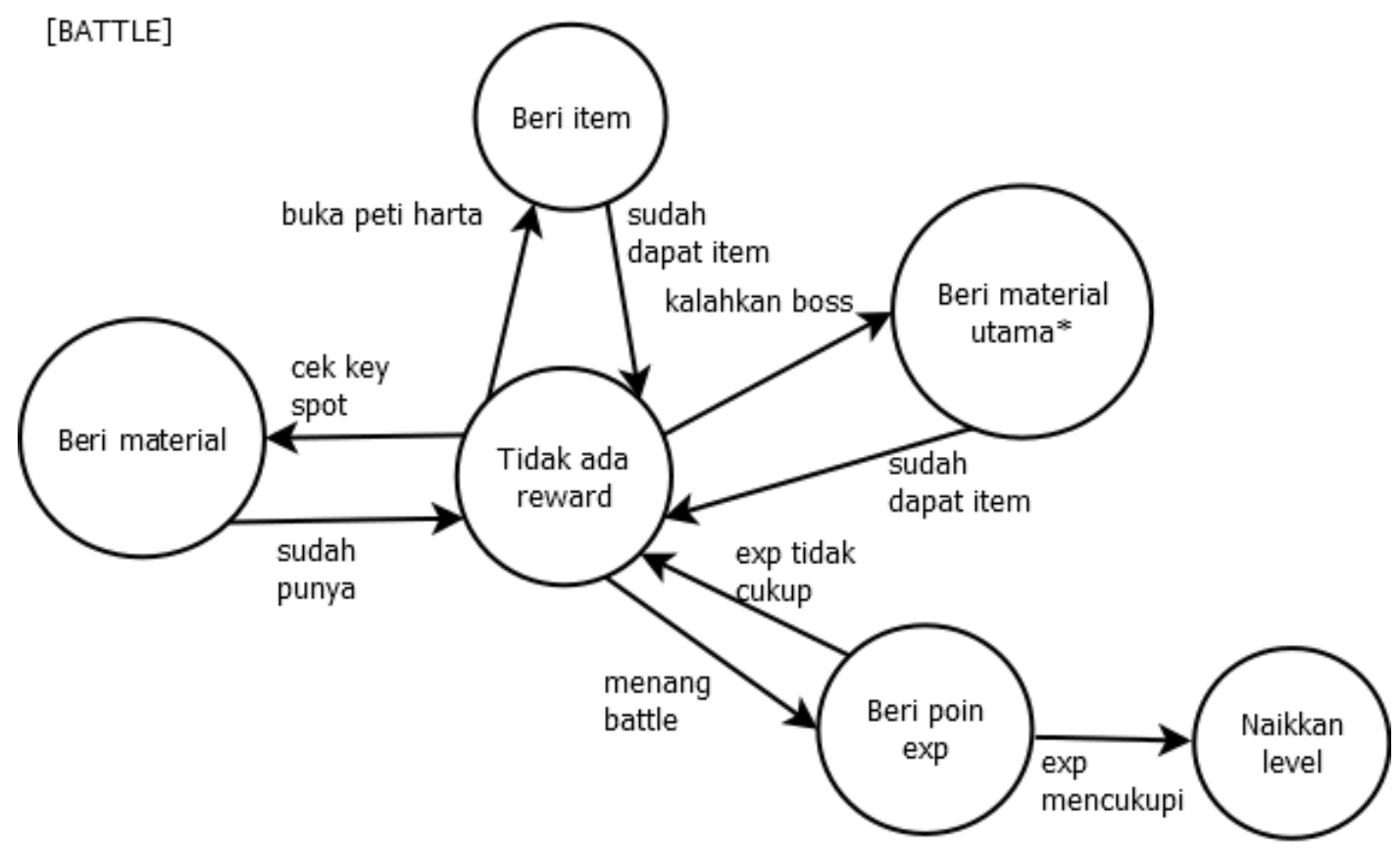

[CRAFT]

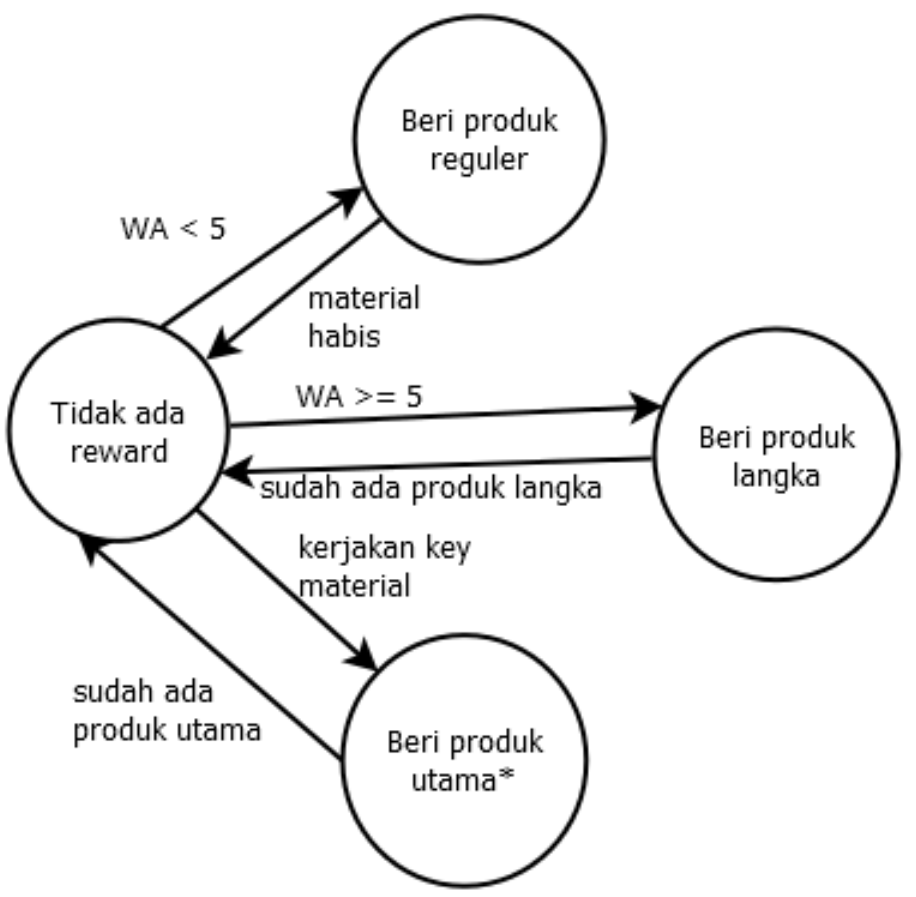

WA $=$ Wisdom Attribute

${ }^{*}$ Reward utama

Gambar 7. Perilaku reward pada tahap Design 
Pada tahap Design, terdiri dari dua aktivitas, yaitu mencari material untuk produk dan membuat produk. Reward utama dari aktivitas mencari produk adalah material utama yang akan digunakan untuk membuat produk. Selain itu, pemain juga dapat mencari material tambahan untuk membuat produk tambahan. Di tahap ini, pemain juga dapat mengalahkan monster untuk memperoleh poin experience yang dapat menaikkan level pemain. Pemain juga dapat menemukan item di lokasi tertentu.

Aktivitas berikutnya adalah membuat produk. Pada aktivitas ini, atribut kebijaksanaan (WA) akan berpengaruh terhadap kualitas produk yang dibuat. Makin tinggi WA akan menyebabkan produk yang dibuat semakin bagus.

\subsubsection{Perilaku Reward pada tahap Destiny}

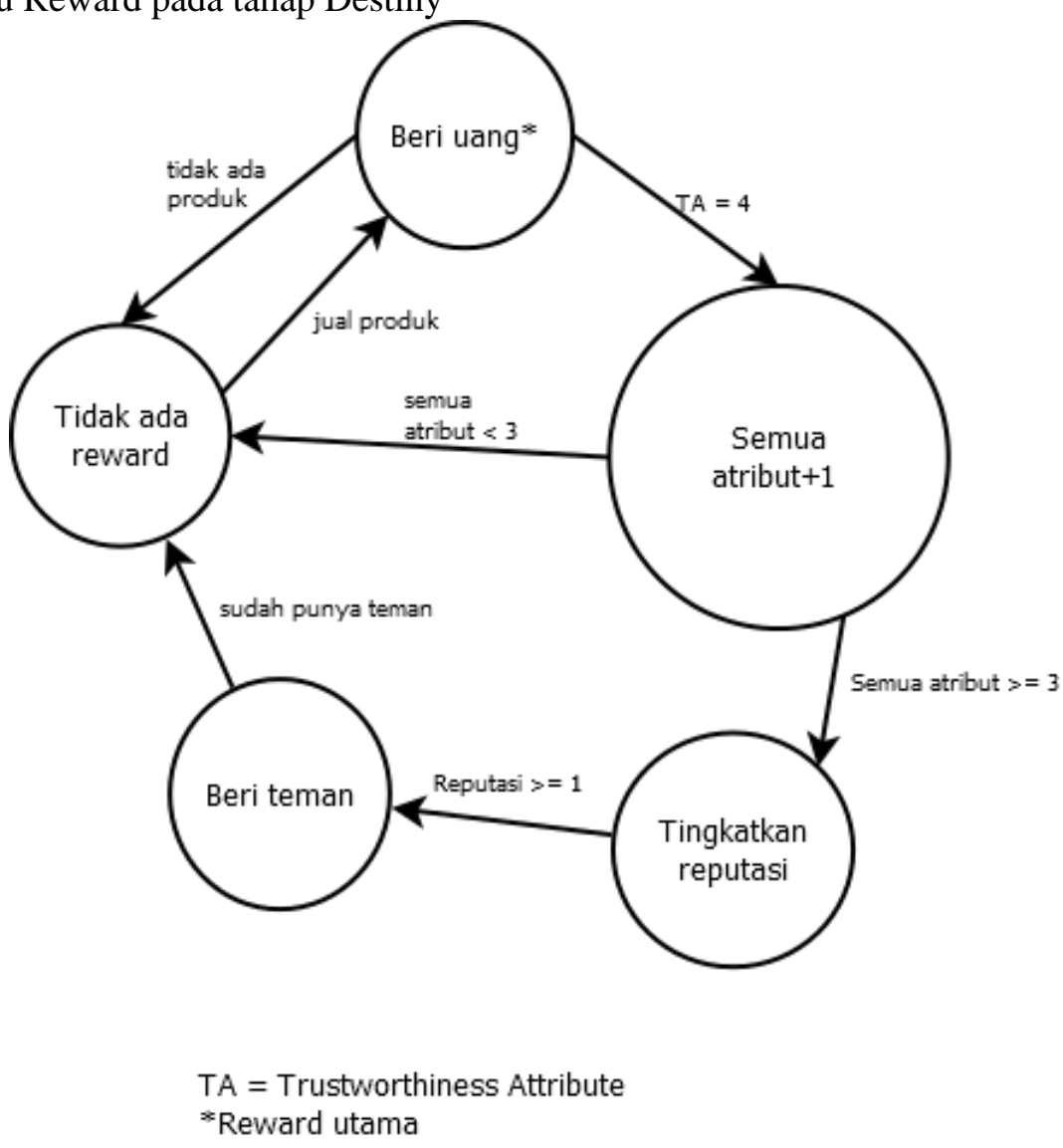

Gambar 8. Perilaku reward pada tahap Destiny

Tahap Destiny adalah tahap dimana pemain akan menjual produknya yang sudah jadi. Besar uang yang didapatkan dipengaruhi oleh kualitas produk yang dihasilkan pada tahap Design. Jika tingkat kepercayaan (TA) pemain mencapai 4 maka akan meningkatkan semua atribut dan jika semua atribut lebih dari atau sama dengan 3 maka akan meningkatkan reputasi. Jika reputasi bertambah, agen cerdas akan mengatur supaya ada teman yang bergabung dengan pemain.

\section{KESIMPULAN}

Penelitian ini memodelkan agen cerdas menggunakan Finite State Machine sebagai pemodelan perilaku dari reward. Perilaku adaptif dari reward terkonsep dan terstruktur menggunakan model Appreciative Learning. Agen cerdas yang dihasilkan 
dapat menyediakan personalisasi reward kepada pemainnya sehingga menyediakan pengalaman belajar praktis yang dapat membantu pemain untuk dapat menumbuhkan jiwa kewirausahaan. Sistem reward yang digunakan dalam game terkonsep dengan baik dan mempunyai tahapan yang jelas dengan menggunakan Appreciative Learning.

\section{SARAN}

Personalisasi reward dalam penelitian ini masih terbatas karena menggunakan Finite State Machine yang perilakunya terbatas, sehingga jika dimainkan berulangkali maka pemain akan dapat dengan mudah mengenali pola reward yang didapatkan sehingga lama kelamaan akan menjadi mudah ditebak dan monoton, padahal salah satu aktivitas penting pembelajaran adalah perulangan pembelajaran materi. Game ini dapat memberikan perulangan yang baik untuk sekitar 2-3 kali namun akan menjadi monoton jika lebih dari itu. Maka penelitian selanjutnya dapat menggunakan metode kecerdasan buatan seperti Fuzzy Logic untuk dapat memberikan variasi reward yang lebih banyak dan lebih sukar ditebak. Dari sisi materi kewirausahaan juga hanya mencakup materi secara umum dan tidak detail, jadi untuk penelitian ke depan dapat berfokus pada satu bagian materi secara mendalam.

\section{DAFTAR PUSTAKA}

[1] M. Wawer, M. Miloz, P. Muryjas, and M. Rzemieniak, "Business Simulation Games in Forming of Students' Entrepreneurship," Int. J. Econ. Manag. Sci., vol. Vol 3, no. 1, p. Pages 49-71, 2010.

[2] R. S. H. Wahyuningsih and I. N. Qamari, "Eksplorasi Urgensi Pembelajaran Kewirausahaan di Perguruan Tinggi," in TOWARDS EXCELLENT SMALL BUSINESS, 2011, pp. 236-258.

[3] M. Simkova, "Using of Computer Games in Supporting Education," Procedia - Soc. Behav. Sci., vol. 141, pp. 1224-1227, 2014.

[4] M. Vinogradova and N. Ivanova, "Pedagogical Conditions for Role-Playing Game Development in Senior Preschool Age Children," Procedia - Soc. Behav. Sci., vol. 233, no. May, pp. 297-301, 2016.

[5] C. V. Zalka, "Adventures in the Classroom Creating Role-Playing Games Based on Traditional Stories for the High School Curriculum," East Tennessee State University, 2012.

[6] I. Mayer, R. Kortmann, I. Wenzler, Á. Wetters, and J. Spaans, "Game-Based Entrepreneurship Education: Identifying Enterprising Personality, Motivation and Intentions Amongst Engineering Students," J. Entrep. Educ., vol. 17, no. 2, pp. 217-245, 2014.

[7] D. La Guardia, M. Gentile, V. Dal Grande, S. Ottaviano, and M. Allegra, "A Game based Learning Model for Entrepreneurship Education," Procedia - Soc. Behav. Sci., vol. 141, pp. 195-199, 2014.

[8] I. Sidhu, C. Johnsson, K. Singer, and M. Suoranta, "A Game -Based Method for Teaching Entrepreneurship,” Appl. Innov. Rev., no. 1, pp. 51-65, 2015.

[9] R. Lopes and R. Bidarra, "Adaptivity challenges in games and simulations: A survey," IEEE Trans. Comput. Intell. AI Games, vol. 3, no. 2, pp. 85-99, 2011.

[10] H. Haryanto, R. Haryanto, and Sugiyanto, "Action Recognition System Using Finite State Machine for Support of Adaptive Reward System in an Elementary Student Education Game My Citations," in Sustainable Design in Creative Industry Towards Better Human Life International Conference on Creative Industry 2011, 2011. 
[11] H. Haryanto, "Reward Dinamis dalam Skenario Adaptif Menggunakan Metode Finite State Machine pada Game Edukasi Dynamic Reward in Adaptive Scenario Using Finite State Machine for Education Game," J. Appl. Intell. Syst., vol. 1, no. 2, pp. 144-153, 2016.

[12] Y. Leng, W. Ali, W. a N. Zah, M. Rosnaini, and B. Roselan, "Appreciative Learning Approach: A New Pedagogical Option," Proc. 18th Int. Conf. Comput. Educ., pp. 607614, 2010.

[13] S. Russel and P. Norvig, Artificial Intelligence: A Modern Approach, 3rd ed. London: Pearson, 2009. 